\title{
LETTER OF RIGHTS FOR PERSONS ARRESTED ON THE BASIS OF A EUROPEAN ARREST WARRANT: A NOVELTY UNDER THE DIRECTIVE 2012/13/EU
}

\author{
Libor Klimek $^{1}$ \\ Faculty of Law, Pan European University, Bratislava, Slovakia \\ email: libor.klimek@paneurouni.com
}

KLIMEK, Libor. Letter of Rights for Persons Arrested on the Basis of a European Arrest Warrant: A Novelty under the Directive 2012/13/EU. International and Comparative Law Review, 2013, Vol. 13., No. 1, pp. 163-170.

DOI: 10.1515/iclr-2016-0066.

Abstract: The paper deals with a Letter of rights for persons arrested on the basis of a European arrest warrant, a novelty introduced by the Directive 2012/13/ EU on the right to information in criminal proceedings. The Directive stipulates that Member States of the EU shall ensure that persons who are arrested for the purpose of the execution of an European arrest warrant are provided promptly with appropriate Letter of rights containing information on their rights according to the law implementing the Framework Decision 2002/584/JHA on the European arrest warrant in the executing Member State. The paper is divided into three sections. First section presents fundamental knowledge on starting points of the letter of rights. Further, second section analyses its legal basis, i.e. Directive 2012/13/EU. The last third section introduces an indicative model of letter of rights.

Keywords: Letter of rights, European arrest warrant, surrender proceedings, strengthening procedural rights, right to information

1 JUDr. Libor Klimek graduated from the Faculty of Law, Bratislava College of Law in 2010. He then became a Ph.D. student in the field of Criminal law at the Faculty of Law, Pan European University, Bratislava (formerly known as Bratislava College of Law). All his research work and publications are focused solely on the international, European and EU aspects of Criminal law. He is the author of over 30 publications published in the USA, Russia, the Netherlands, Belgium, Poland, the Czech Republic, Latvia and, naturally, the Slovak Republic; contact: libor.klimek@ yahoo.com 


\section{Introduction}

In May 2012 was adopted the Directive 2012/13/EU on the right to information in criminal proceedings ${ }^{2}$ (hereinafter 'Directive'), which has impact on the European arrest warrant (hereinafter 'EAW'). ${ }^{3}$ It introduces two novelties - first - a Letter of rights on arrest, which shall apply to criminal proceedings in general, and - second - a Letter of rights for persons arrested on the basis of an EAW, which shall apply to surrender proceedings under the Framework Decision 2002/584/ JHA on the EAW and the surrender procedures between Member States. ${ }^{4}$

As far as the surrender proceedings are concerned, the Directive stipulates that Member States of the EU shall ensure that persons who are arrested for the purpose of the execution of an EAW are provided promptly with appropriate Letter of rights containing information on their rights according to the law implementing the Framework Decision 2002/584/JHA on the EAW in the executing Member State. Member States of the EU shall bring into force the laws, regulations and administrative provisions necessary to comply with the Directive by 2 June 2014 .

As is obvious, the article deals with the Letter of rights for persons arrested on the basis of an EAW, a novelty introduced by the aforementioned Directive. It is divided into three sections. Section 1 presents fundamental knowledge on starting points of the letter of rights. Further, section 2 analyses its legal basis, i.e. Directive 2012/13/EU on the right to information in criminal proceedings. The last section 3 presents an indicative model of letter of rights.

\section{Starting Points of the Letter of Rights}

Letter of rights for persons arrested on the basis of the EAW is a result of the development of political and legal documents introduced and presented by the top EU institutions.

2 Directive 2012/13/EU of the European Parliament and of the Council of 22 May 2012 on the right to information in criminal proceedings. OJ, L 142/1 of 1.6.2012.

3 The EAW is a judicial decision issued by a Member State of the EU with a view to the arrest and surrender by another Member State of a requested person, for the purposes of conducting a criminal prosecution or executing a custodial sentence or detention order. See KLIMEK, L.: European Arrest Warrant: Procedural Instrument for Public Order Enforcement in the EU's Area of Freedom, Security and Justice. In: BĚLOHLÁVEK, A. J. et ROZEHNALOVÁ, N. (eds.): Czech Yearbook of International Law 2012, Vol. 3. Juris Publishing : New York - USA, 2012, pp. 3-18; or HAMULÁK, O.: Eurozatykač, tři ústavní soudy a dominance práva Evropské unie [transl.: European Arrest Warrant, three Constitutional Courts and Dominance of European Union Law]. Olomouc : Iuridicum Olomoucense, 2011.

4 Council Framework Decision 2002/584/JHA of 13 June 2002 on the European arrest warrant and the surrender procedures between Member States (as amended by the Council Framework Decision 2009/299/JHA of 26 February 2009). OJ, L 190/1 of 18.7.2002. 
The European Council held a special meeting on 15 and 16 October 1999 in Tampere ${ }^{5}$ on the creation of an Area of freedom, security and justice ${ }^{6}$ in the EU. It sent a strong political message to reaffirm the importance of this objective and agreed on a number of policy orientations and priorities which would speedily make this area a reality. The 1999 Tampere European Council concluded that enhanced mutual recognition of judicial decisions and judgements and the necessary approximation of legislation would facilitate co-operation between authorities and the judicial protection of individual rights. ${ }^{7}$

Furthermore, in Hague Programme ${ }^{8}$ of 2004, the European Council argued that further realisation of mutual recognition as the cornerstone of judicial cooperation implies the development of equivalent standards of procedural rights in criminal proceedings. ${ }^{9}$

On $30^{\text {th }}$ November 2009 - the last day of the III Pillar of the EU - the Council of the EU adopted a Roadmap for strengthening procedural rights of suspected or accused persons in criminal proceedings ${ }^{10}$ (hereinafter 'Roadmap'). Under the Roadmap, action should be taken at the level of the EU in order to strengthen the rights of suspected or accused persons in criminal proceedings. The Commission was invited to submit proposals regarding the measures set out in the Roadmap, namely: translation and interpretation (measure A); information on rights and information about the charges (measure B); legal advice and legal aid (measure C); communication with relatives, employers and consular authorities (measure D); special safeguards for suspected or accused persons who are vulnerable (measure E); and to consider presenting a Green Paper on pre-trial detention (measure F). It is worth mentioning that the scope of these measures is not focused exclusively on criminal proceedings, but some of them are related also to the EAW, i.e. the surrender proceeding.

Two legislative measures have been adopted so far, namely a Directive 2010/64/EU on the right to interpretation and translation in criminal proceedings $^{11}$, introducing the A measure ${ }^{12}$, and a Directive 2012/13/EU on the right to

5 See Presidency Conclusions, Tampere European Council of 15-16 October 1999. In: VERMEULEN, G.: Essential texts on International and European Criminal Law. $4^{\text {th }}$ edition. Antwerpen Apeldoorn : Maklu, 2005, pp. 327-341.

6 Nowadays, the Area of freedom, security and justice is the second objective of the EU. See Article 3 of the Treaty on EU as amended by the Treaty of Lisbon. OJ, C 83/13 of 30.3.2010.

7 Point 33 of the Tampere European Council conclusions.

8 OJ, C 53/1 of 3.3.2005.

9 Point 3.3.1 of the Hague Programme.

10 Resolution of the Council of 30 November 2009 on a Roadmap for strengthening procedural rights of suspected or accused persons in criminal proceedings. OJ, C 295/1 of 4.12.2009.

11 Directive 2010/64/EU of the European Parliament and of the Council of 20 October 2010 on the right to interpretation and translation in criminal proceedings. OJ, L 280/1 of 26.10.2010. Member States of the EU shall bring into force the laws, regulations and administrative provisions necessary to comply with this Directive by 27 October 2013.

12 See KLIMEK, L.: Právo na tlmočenie a preklad v trestnom konani v EÚ: nové opatrenie na posilnenie 
information in criminal proceedings, introducing the B measure. Moreover, the European Commission has introduced a Proposal for a Directive on the right of access to a lawyer in criminal proceedings and on the right to communicate upon arrest $^{13}$, in connection to the $\mathrm{C}$ measure. Furthermore, it introduced also a Green Paper on the application of EU criminal justice legislation in the field of detention ${ }^{14}$, in connection to the F measure ${ }^{15}$ As far as the $\mathrm{D}$ and $\mathrm{E}$ measures are concerned, no proposals have been introduced.

\section{Legal Basis: Directive 2012/13/EU on the Right to Information in Criminal Proceedings}

Broadly speaking, the right to information has been recognised as a fundamental human right. ${ }^{16}$ In the Criminal law area, the right to information is considered to be a crucial aspect of the overall right to defend oneself. ${ }^{17}$ The European Council argues that a person that is suspected or accused of a crime should get information on his/her basic rights orally or, where appropriate, in writing, e.g. by way of a Letter of Rights. Furthermore, that person should also receive information promptly about the nature and cause of the accusation against him or her. A person who has been charged should be entitled, at the appropriate time, to the information necessary for the preparation of his or her defence, it being understood that this should not prejudice the due course of the criminal proceedings. ${ }^{18}$

As a result of aforementioned steps, in May 2012 was adopted the Directive 2012/13/EU on the right to information in criminal proceedings. It is addressed to the Member States of the EU, excluding Denmark. ${ }^{19}$ They shall bring into force

procesných práv podozrivých alebo obvinených osôb [transl.: The Right to Interpretation and Translation in Criminal Proceedings in the EU: A New Measure for Strengthening Procedural Rights of Suspected or Accused Persons]. In: Časopis pro právní vědu a praxi, Vol. 20, No. 2/2012, pp. 19-24; KLIMEK, L.: Právo na tlmočenie a preklad v konaní o európskom zatýkacom rozkaze osôb [transl.: Right to Interpretation and Translation in the European Arrest Warrant Procedure]. In: Justičná revue, Vol. 63, No. 2 (2011), pp. 262-269.

13 Proposal for a Directive of the European Parliament and of the Council on the right of access to a lawyer in criminal proceedings and on the right to communicate upon arrest. $\operatorname{KOM(2011)~} 326$ final.

14 Strengthening mutual trust in the European judicial area - A Green Paper on the application of EU criminal justice legislation in the field of detention. KOM(2011) 327 final.

15 See KLIMEK, L.: Posilnenie procesných práv v trestnom konaní: aktuálny vývoj legislatívnych opatrení v EÚ [transl.: Strengthening Procedural Rights in Criminal Proceedings: Current Development of Legislative Measures of the EU]. In: Trestní právo, Vol. 15, No. 10 (2011), pp. 22-27.

16 SHRIVASTAVA, K. M.: The Right to Information : A Global Perspective. Frankfort : Lancer Publishers, 2009, s. 1.

17 SPRONKEN, T. - De VOCHT, D. - VERMEULEN, G. et Van PUYENBROECK, L.: EU Procedural Rights in Criminal Proceedings. Antwerp - Apeldoorn - Portland : Maklu, 2009, p. 25.

18 Resolution of the Council of 30 November 2009 on a Roadmap for strengthening procedural rights of suspected or accused persons in criminal proceedings. OJ, C 295/1 of 4.12.2009.

19 Denmark is not taking part in the adoption of the Directive and is not bound by it or subject to 
the laws, regulations and administrative provisions necessary to comply with the Directive by 2 June 2014.

The Directive is based on the Treaty on the Functioning of the EU, which stipulates that minimum rules concerning the rights of individuals in criminal proceedings may be adopted by means of directives to the extent necessary to facilitate mutual recognition of judgments and judicial decisions and police and judicial co-operation in criminal matters having a cross-border dimension. ${ }^{20}$

It should be explained why the EU is better placed to take action than its Member States. The EU is establishing its own, unique system of judicial cooperation based on the principle of mutual recognition throughout the EU. ${ }^{21}$ Such a novel system calls for a guarantee of uniformly high standards of fundamental procedural rights protection in the EU. Considering that there is wide variation between Member States on the content, means and timing of information on rights and on the charge provided to suspects and accused persons, it is unlikely that Member States acting individually would be able to establish a sufficiently consistent standard of provision of information. There are no indications that Member States would provide for raising and approximation of standards of informing accused persons of the charge against them. Whilst a majority of Member States of the EU already use largely identical means of informing accused persons of the charge, there is still significant variance in the precise way and timing of the provision of this information which leads to a divergence of standards in relation to this information across the EU. ${ }^{22}$

The Directive lays down, first, rules concerning the right to information of suspects or accused persons, relating to their rights in criminal proceedings and to the accusation against them, and second, rules concerning the right to information of persons subject to a European arrest warrant relating to their rights. ${ }^{23}$ Thus, the Directive deals with the EAW proceedings, i.e. surrender proceedings, which in 2002 replaced extradition ${ }^{24}$ (as far as EU is concerned).

The Directive promotes the application of the Charter of Fundamental Rights of the EU and the European Convention on Human Rights and Fundamental

its application, in accordance with Articles 1 and 2 of the Protocol (No 22) on the position of Denmark, annexed to the Treaty on EU and to the Treaty on the Functioning of the EU. OJ, C $83 / 299$ of 30.3 .2010 .

20 Article 82(2)(b) of the Treaty on the functioning of the EU as amended by the Treaty of Lisbon. OJ, C 83/47 of 30.3.2010.

21 See Article 82(1) of the Treaty on the functioning of the EU as amended by the Treaty of Lisbon.

22 Impact assessment accompanying the Proposal for a Directive of the European Parliament and of the Council on the right to information in criminal proceedings. SEC(2010) 907, p. 16.

23 Article 1 of the Directive.

24 See KLIMEK, L.: Surrender vs. Extradition: A Comparison Focused on Innovations of European Arrest Warrant. In: International and Comparative Law Review, Vol. 11, No. 1 (2011), pp. 139150. 
Freedoms $\mathrm{s}^{25}$ as interpreted by the European Court of Human Rights. However, as shown, it lays down minimum rules with respect to the information on rights of suspects or accused persons. Member States may extend the rights set out in the Directive in order to provide a higher level of protection also in situations not explicitly dealt with in the Directive. The level of protection should never fall below the standards provided by the European Convention on Human Rights as interpreted in the case-law of the European Court of Human Rights. On the one hand, this is without prejudice to information to be given on other procedural rights arising out of the Charter of Fundamental Rights of the $\mathrm{EU}^{26}$, the European Convention on Human Rights, national law and applicable EU law as interpreted by the relevant courts and tribunals. On the other hand, once the information about a particular right has been provided, the competent authorities should not be required to reiterate it, unless the specific circumstances of the case or the specific rules laid down in national law so require.

As far as the scope of the Directive is concerned, it applies from the time persons are made aware by the competent authorities of a Member State that they are suspected or accused of having committed a criminal offence until the conclusion of the proceedings. Thus, it applies until the final determination of the question whether the suspect or accused person has committed the criminal offence, including, where applicable, sentencing and the resolution of any appeal. Where the law of a Member State provides for the imposition of a sanction regarding minor offences by an authority other than a court having jurisdiction in criminal matters, and the imposition of such a sanction may be appealed to such a court, the Directive shall apply only to the proceedings before that court, following such an appeal. ${ }^{27}$

The Directive stipulates rules on certain rights, namely: right to information about rights; right to letter of rights on arrest; right to letter of rights in EAW proceedings; right to information about the accusation; right of access to the materials of the case; and right to verification and remedies. ${ }^{28}$

\section{Indicative Model of Letter of rights in EAW proceedings}

As shown, Member States of the EU shall ensure that persons who are arrested for the purpose of the execution of an EAW are provided promptly with appropriate Letter of rights containing information on their rights according to the law implementing the Framework Decision 2002/584/JHA on the EAW in the executing Member State. ${ }^{29}$

25 European Treaty Series No. 005 [1950].

26 OJ, C 83/389 of 30.3.2010.

27 Article 2 of the Directive.

28 Articles 3-8 of the Directive.

29 Article 5(1) of the Directive. 
The Letter of rights shall be drafted in simple and accessible language. An indicative model Letter of rights is set out in Annex II to the Directive. The sole purpose of the model is to assist national authorities in drawing up their Letter of rights at national level. Member States are not bound to use the model. When preparing their Letter of Rights, Member States may amend this model in order to align it with their national rules and add further useful information. Under the indicative model, Letter of rights should include information about the EAW, assistance of a lawyer, interpretation and translation, possibility to consent, and hearing.

However, the provisions on Letter of rights in EAW proceedings do not include standards regarding language. Analogically, taking into account provisions on the Letter of rights on arrest, which shall apply to criminal proceedings in general, persons arrested on the basis of the EAW should receive the Letter of rights written in a language that they understand. Where a Letter of rights is not available in the appropriate language, they should be informed of their rights orally in a language that they understand. A Letter of rights in a language that they understand should then be given to them without undue delay. ${ }^{30}$ Thus, the Directive does not require maternal language (one's native language). It is sufficient a language that a person understand. In comparison, in case of the European Convention on Human Rights and Fundamental Freedoms, everyone who is arrested shall be informed promptly, in a language which he understands, of the reasons for his arrest and of any charge against him. ${ }^{31}$

\section{Conclusion}

As far the European arrest warrant is concerned, the Directive 2012/13/EU on the right to information in criminal proceedings introduces a novelty - a Letter of rights for persons arrested on the basis of an European arrest warrant, which shall apply to surrender proceedings under the Framework Decision 2002/584/JHA on the European arrest warrant and the surrender procedures between Member States.

Letter of rights for persons arrested on the basis of the European arrest warrant is a result of the development of political and legal documents introduced and presented by the top EU institutions. The Council of the EU adopted a Roadmap for strengthening procedural rights of suspected or accused persons in criminal proceedings. Under the Roadmap, action should be taken at the level of the EU in order to strengthen the rights of suspected or accused persons in criminal proceedings. As a consequence, in May 2012 was adopted aforementioned directive.

30 Article 4(5) of the Directive.

31 Article 5(2) of the European Convention on Human Rights and Fundamental Freedoms. 
ICLR, 2013, Vol. 13, No. 1.

The Directive, inter alia, lays down rules concerning the right to information of persons subject to a European arrest warrant relating to their rights. Member States of the EU shall ensure that persons who are arrested for the purpose of the execution of an EAW are provided promptly with appropriate Letter of rights containing information on their rights according to the law implementing the Framework Decision 2002/584/JHA on the EAW in the executing Member State. They shall bring into force the laws, regulations and administrative provisions necessary to comply with the Directive by 2 June 2014. 